\title{
Tverrfaglig tilbud om dagrehabilitering
}

Pasienter med kroniske, sammensatte plager har behov for individuelt tilpasset rehabilitering.

\section{Forfattere}

\section{Mette Horten Arnstad}

Spesialsykepleier og fagleder

Dagrehabiliteringen ved Meråker Sanitetsforenings Kurbad

\section{Grete Estil}

Spesialfysioterapeut

Dagrehabiliteringen ved Meråker Sanitetsforenings Kurbad

\section{Nøkkelord}

\begin{tabular}{|l|l|l|l}
\hline Dagrehabilitering tverrfaglig Kronisk sykdom Livskvalitet &
\end{tabular}

Sykepleien 2017 105(64262)(e-64262)

DOI: https://doi.org/10.4220/Sykepleiens.2017.64262

\section{HOVEDBUDSKAP}

Pasienter som lever med kroniske, sammensatte plager, har behov for og nytte av et tverrfaglig spesialisert dagrehabiliteringstilbud. Det er viktig å kartlegge og sette i gang tiltak for å hjelpe hele mennesket fysisk, psykisk og sosialt. Når pasientene får økt innsikt i og forståelse for egen sykdom og livssituasjon, vil de kunne mestre hverdagen bedre.

Vi er en del av et tverrfaglig team i dagrehabiliteringstilbudet ved Meråker Sanitetsforenings Kurbad. I denne erfaringsbaserte artikkelen ønsker vi å belyse hvilken effekt pasienter kan ha av et tverrfaglig dagrehabiliteringstilbud innenfor spesialisthelsetjenesten. 
Videre ønsker vi å gjøre rede for erfaringene så langt med dette behandlingstilbudet, både erfaringene til det tverrfaglige teamet og den enkelte pasienten. Med dette som utgangspunkt ønsker vi å se på både årsaker og sammenhenger som kan forklare resultatene vi fikk.

\section{Behandlingsopplegget}

I sin helhet består rehabiliteringstilbudet av smertereduserende tiltak, fysisk trening både individuelt og i gruppe samt kognitivt rettete tiltak gjennom individuelle samtaler, gruppeveiledning og felles undervisning med refleksjon.

Vi gjennomførte behandlingsopplegget på 14 grupper, med i gjennomsnitt fem pasienter i hver gruppe fra april 2014. Ved innkomst og utreise brukte vi et skaleringsskjema med ulike fysiske og psykiske parametere som måleinstrument samt et kroppskart for å kartlegge hvor pasienten hadde smerter.

Vi benyttet også et evalueringsskjema om behandlingsopplegget, som pasientene besvarte da de reiste fra kurbadet. Med disse skjemaene fikk vi et totalinntrykk av pasientenes utbytte av behandlingen.

\section{Dagrehabiliteringen}

Dagrehabiliteringstilbudet finner sted to hele dager i uken over en periode på fem uker. Tilbudet er gruppebasert med plass til fem-seks pasienter og tilpasses hver enkelt pasient.

\section{三 «Diagnosene er komplekse og sammensatte, og pasientene har både fysiske og psykiske utfordringer i hverdagen.»}


Vi tar imot pasienter med ulike diagnoser som trenger tverrfaglig spesialisert rehabilitering. De diagnosene vi har hatt på dagrehabiliteringen så langt, er først og fremst av kronisk og langvarig art, slik som ulike revmatiske diagnoser, fibromyalgi og andre smertetilstander, kreft, tidligere skader og slagdiagnoser.

Diagnosene er komplekse og sammensatte, og pasientene har både fysiske og psykiske utfordringer i hverdagen. Pasientenes alder har variert fra 26 til 82 år, men de fleste har vært mellom 30 og 70 år gamle.

\section{Fagbemanning}

En spesialsykepleier, en spesialfysioterapeut og en spesialergoterapeut er ansatt ved dagrehabiliteringen. Dette tverrfaglige teamet har spesialkompetanse på revmatologi, slag, kreft, muskel- og skjelettlidelser, kroniske smerter samt veiledningspedagogikk og livsstyrketrening.

En spesialist i allmennmedisin skriver inn nye pasienter. Vi har også anledning til å benytte oss av annet spesialpersonell ved behov, som sosionom, idrettspedagog, logoped, revmatolog, ortoped og psykiater.

\section{Mål med tilbudet}

Formålet med vårt rehabiliteringsopplegg er følgende:

- fokusere tidlig på hverdagsmestring for å få bedre kvalitet i rehabiliteringsprosessen

- gjenvinne best mulig fysisk og psykisk funksjonsnivå

- få økt innsikt i tanker og vanemønstre for å kunne styrke egne ressurser

- bli bevisst på egne valg

- bli motivert til å ha en mer aktiv hverdag med mer fysisk aktivitet

\section{Kartlegging}


Når pasienten kommer til tverrfaglig innskriving første dag, kartlegger vi personlige opplysninger og sykehistorie. Pasienten setter selv hovedmål og delmål for dagoppholdet. Videre blir pasienten kartlagt og undersøkt individuelt av en fra hver fagprofesjon for å få en mest mulig tverrfaglig tilnærming. Fysioterapeuten foretar en undersøkelse og funksjonsvurdering. Ergoterapeuten kartlegger pasientens hverdag og gjøremål ved å bruke et aktivitetshjul.

Både ved innkomst og utreise kartlegger sykepleieren pasientens fysiske og psykiske tilstand ved hjelp av et skaleringsskjema og kroppskart over framsiden og baksiden av kroppen. På kroppskartet fargelegger pasienten de områdene av kroppen som er smertefulle. I tillegg oppgir de en beskrivelse av smertene.

\section{三 «Pasienten setter selv hovedmål og delmål for dagoppholdet.»}

Etter at vi er ferdige med målsetting, kartlegging og funksjonsundersøkelse, forankrer vi tiltakene tverrfaglig.

\section{Tiltak}

Rehabiliteringsopplegget er en kombinasjon av individuelle tiltak og gruppetiltak. Alle pasientene får et individuelt tilpasset treningsprogram som er tilrettelagt av fysioterapeut på bakgrunn av sykehistorie og undersøkelse. Dette programmet omfatter som regel kondisjon, utholdenhet, styrke, bevegelighet og balanse. Vi justerer programmet kontinuerlig under oppholdet, enten når pasienten har progresjon eller eventuelt forverret sykdomsaktivitet. 
De som har muskel-, leddsmerter og spenninger som begrenser aktiviteten og utfoldelsen i hverdagen, får tilbud om smertereduserende tiltak som blant annet varme- eller kuldebehandling, massasje, tøyning, mobilisering og nålebehandling. Pasientene har også fellesøvelser i varmebasseng én time per uke. Sykepleieren har samtaler med hver enkelt deltaker når de skal fylle ut skaleringsskjemaet og kroppskartet.

I begynnelsen av oppholdet underviser ergoterapeuten om aktiviteter i hverdagen, og pasienten får med seg en aktivitetsdagbok. De blir oppfordret til å bruke dagboken aktivt. Pasientene skal selv kartlegge sin egen hverdag ved å bruke et aktivitetshjul: «Hvordan er hverdagen din nå?» De skal fylle ut hvor stor del de forskjellige aktivitetene tar av hverdagen deres.

Etter en uke får pasientene en individuell samtale, veiledning og gjennomgang av aktivitetshjulet med ergoterapeuten. Etter denne samtalen får de med seg et nytt aktivitetshjul: «Hvordan ønsker du at din hverdag skal se ut?» Aktivitetshjulet spør også om hvorvidt de ser noen praktiske og konkrete muligheter til løsninger og endringer i hverdagen.

Uken etter er det en ny samtale og gjennomgang av aktivitetshjul nummer to. Etter denne samtalen skal pasientene selv sette opp en plan over hvordan de skal endre hverdagen slik at den blir til det bedre. I slutten av oppholdet går en ergoterapeut gjennom dagboken, og vi kan da se om det har skjedd en endring hos pasienten.

\section{Gruppeveiledning}

Det blir satt opp gruppeveiledning én til to ganger i uken. Alle tre i det tverrfaglige teamet har veiledningskompetanse. Til enhver tid er det to veiledere i gruppen: en hovedveileder samt en medveileder. De benytter kunnskapsbaserte og anerkjente pedagogiske og psykologiske metoder som livsstyrketrening og veiledningspedagogikk. 
Innenfor livsstyrketrening jobber vi ut fra forståelsen om at tanker, følelser, kropp og levd liv henger sammen, og at kroppslige helseplager kan være et uttrykk for at «livet setter seg i kroppen».

Formålet med veiledningsmetodene er å kunne identifisere hva plagene og utfordringene i hverdagen kan henge sammen med. Ofte ser vi at plagene hos én person kan være et uttrykk for en ubalanse som har vart over tid.

Når veiledningen foregår i gruppe, innebærer det at deltakerne kan dele og reflektere sammen om erfaringer, utfordringer og opplevelser. Deltakerne kan oppleve et fellesskap, og de kan føle at de ikke er alene om å ha et problem.

\section{三 «Veiledningsopplegget har vært tilpasset pasientenes utfordringer med egen sykdom og hverdag.»}

I veiledningen følger vi noen sentrale etiske verdier som alltid ligger til grunn. Vi presiserer at det som blir sagt i gruppeveiledningen, blir holdt innad i gruppen.

Det er frivillig hvor mye den enkelte ønsker å dele.

Deltakeren inviteres til å dele sin erfaring med gruppen. Vi er opptatt av at deltakerne skal føle at de betyr noe i gruppen, og at hvert enkelt bidrag er verdifullt.

Temaer som vi tar opp i gruppeveiledninger, kan være som følger: «hva gir og tar energi», «mine ressurser», «hva er viktig for meg» og «hvis kroppen kunne snakke». Slike livstemaer er inkludert i programmet for livsstyrketrening. 
Veiledningsopplegget har vært tilpasset pasientenes utfordringer med egen sykdom og hverdag. Fem grupper hadde bare veiledning. I sju grupper kombinerte vi veiledning og undervisning for å gi et optimalt tilbud. Dersom vi hadde pasienter som hadde søvnproblemer, valgte vi å undervise i temaet søvn. I to av gruppene hadde pasientene høy alder og slagdiagnose med kognitiv svikt. Derfor valgte vi undervisning med samtale i stedet for veiledning i de gruppene fordi det ikke fungerte med veiledning.

\section{Metode}

I studien vår har vi brukt skaleringsskjema, kroppskart og evalueringsskjema som metode for å belyse hvilken effekt et tverrfaglig dagrehabiliteringstilbud kan ha for pasienter med ulike kroniske diagnoser. Vi brukte slike skjemaer for å fange opp flere faktorer i pasientens helsetilstand for å få et mer helhetlig inntrykk. I og med at vi tar imot pasienter med ulike diagnoser, ønsket vi å ha et skjema som favnet om både psykiske og fysiske faktorer.

\section{Skaleringsskjema}

I skaleringsskjemaet «Hvordan har du det i dag?» graderte pasientene sin fysiske og psykiske tilstand på en skala fra null til ti på en linje, slik som visuell analog skala (VAS) for smerte. Skaleringsskjemaet inneholder følgende ni målevariabler:

- smerter i ro

- smerter i bevegelse

- matlyst

- angst/uro

- tristhet/depresjon

- motivasjon til aktivitet

- trøtthet/slapphet

- $s \varnothing v n$

- alt i alt tatt i betraktning: «Hvordan har du det i dag?» 
Verdien null angir ingen plager, og verdien ti angir verst tenkelige plager. Dette gjelder for målevariablene «smerter i ro», «smerter i bevegelse», «angst/uro», «tristhet/depresjon» og «trøtthet/slapphet». For målevariablene «matlyst», «Søvn», «motivasjon til aktivitet» og «alt i alt tatt i betraktning», er derimot verdien null den verst tenkelige, og verdien ti den beste.

Pasientene fylte ut skaleringsskjemaet ved innkomst og utreise. Deretter sammenliknet vi verdiene for å finne ut om det hadde skjedd en endring. Svakheten med å kalle skjemaet «Hvordan har du det i dag?» er at dagsformen varierer mye for disse pasientene. Det kan derfor være nødvendig å endre tittelen til «Hvordan har du det?».

\section{Kroppskart}

Et kroppskart (se figur 1) gir et visuelt inntrykk av hele kroppen, og pasienten kan få et klarere bilde av hvordan smertene henger sammen. Et kroppskart er en skisse av en framside og bakside på en kropp der pasienten skraverer de smertefulle områdene med rød farge. Sterk rødfarge angir mye smerte, svak rød angir mindre smerte.

Med denne metoden får både behandlingsteamet og pasienten et tydeligere bilde av pasientens smertekarakter, smerteintensitet og rangering av smertene. Kroppskartet kan også gi en oversikt over hvilke smerter vi må prioritere i behandlingen. 

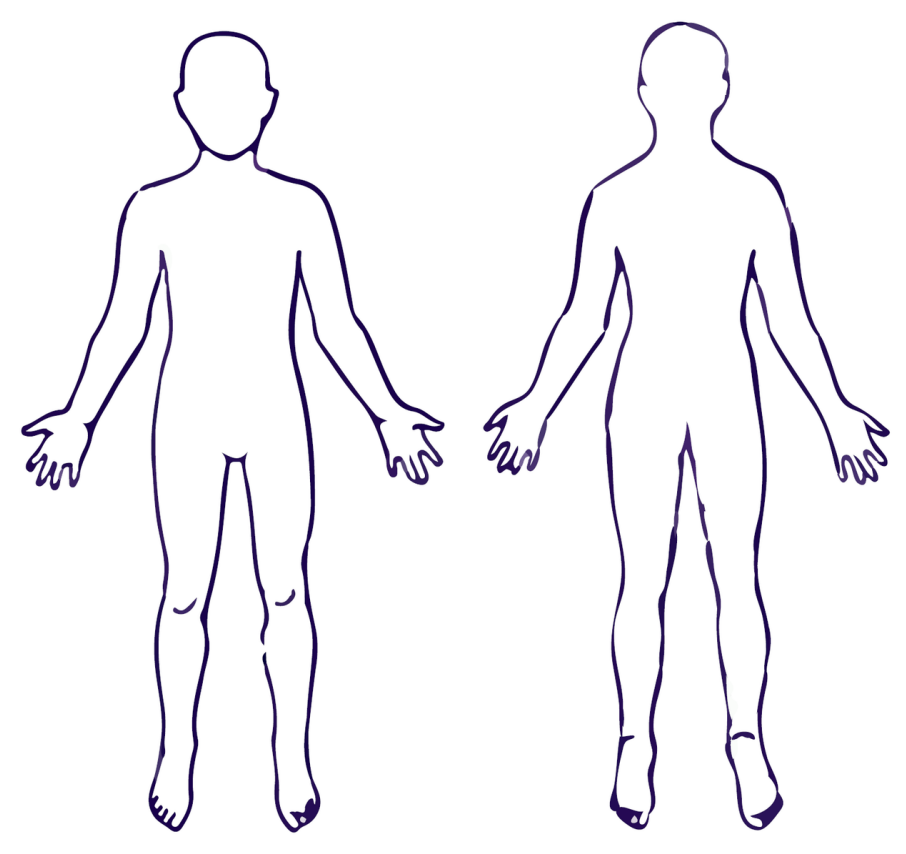

Smertekarakter:

I. Konstant

II. Ujevn

III. Utløst av bevegelse

1. Verkende

2. Pulserende

3. Stikkende

4. Skjærende

5. Rivende

6. Trykkende

7. Brennende

8. Utstrålende

9. Sviende

10. llende

Smertestillende

medisiner:

\section{Evalueringsskjema}

I evalueringsskjemaet evaluerer pasienten anonymt tilbudet på dagrehabiliteringen etter endt opphold. Her svarer pasienten på hva vedkommende har likt ved de ulike delene av tilbudet, samt gir en beskrivelse av utbyttet av de ulike tiltakene vedkommende har deltatt på.

\section{Resultater}

Her tar vi først for oss resultatene av

skaleringsskjemaet og kroppskartet og drøfter mulige årsaker og sammenhenger basert på erfaringene våre. Videre underbygger vi resultatene med pasientenes uttalelser fra evalueringsskjemaet.

\section{Trøtthet/slapphet}


Trøtthet og slapphet, også kalt fatigue, hadde en nedgang fra 5,6 til 5,1, altså en bedring på 0,5. Vi erfarte at pasientene ble mer bevisste på balansen mellom aktivitet og hvile i hverdagen. Flere pasienter uttrykte at de hadde fătt større innsikt i sin egen situasjon etter endt opphold. De var også blitt mer bevisste på å sette tydeligere grenser for seg selv og uttrykke egne behov.

Gjennom aktivitetskartlegging med ergoterapeuten utarbeidet de en dagsplan og en ukeplan for hverdagen hjemme. Disse planene kan ha bidratt til at de innså hvor viktig det er med hvile mellom aktivitetene. Vi fikk også tilbakemeldinger fra flere av pasientene om at et skreddersydd treningsprogram kombinert med varme- og bløtdelsbehandling, som massasje og tøyning, ga smertelindring og bedre søvn - noe som igjen kan ha påvirket energinivået positivt.

\section{Angst/uro}

Angst og uro gikk ned fra 3,3 til 2,5 - en bedring på 0,8 . I pasientenes evalueringsskjema beskrev noen at de hadde fått større bevissthet om hensikten med øvelsene i treningsprogrammet. Dermed fikk de bekreftet at det går greit å trene med akseptable smerter. Disse faktorene kan ha bidratt til å ufarliggjøre plagene samt gi dem mindre bevegelsesvegring. De ble dermed tryggere på å fortsette treningen hjemme.

Vi erfarte dessuten at undervisning og samtaler samt veiledning ga pasientene mer kunnskap om og større forståelse for egen sykdom og håndtering av sykdommen, som igjen kan ha bidratt til mindre angst og uro.

\section{Søvn}


Søvn hadde en bedring fra 5,2 til 6,7. Denne bedringen på 1,5 var den største på alle målevariablene. Vi tror det er flere grunner til dette: Det kan være at de pasientene som oppga bedret søvn ved utreise, også oppga reduserte smerter og mindre stivhet. Kanskje ble kroppen mer fysisk og mentalt sliten gjennom opplegget slik at pasientene fikk bedre søvnkvalitet.

I tillegg fikk pasientene råd og veiledning etter behov om hensiktsmessige hvilestillinger, avspenningsteknikker, medisinering og gode rutiner før leggetid. Som forklart i avsnittet over så vi at pasientene fikk mindre angst og uro. Det kan ha virket positivt på søvnen, slik at denne ble bedre.

\section{Alt i alt}

Målevariabelen «alt i alt» hadde en bedring fra 5,7 til 6,6 - en bedring på 0,9. Etter endt opphold ved dagrehabiliteringen oppga pasientene at de hadde bedre evne til å mestre hverdagen, noe som vi tror kan forklare framgangen. Det kan også ha hatt innvirkning at noen sa at de hadde blitt mer bevisste på egne reaksjoner og handlingsmønstre. Andre uttalte at behandlingen fokuserte på hele mennesket samt påpekte at de ikke var alene om å ha de samme utfordringene.

Pasientene fikk større bevissthet om faktorer som påvirker hverdagen og lærte hvordan de skulle håndtere dem mer hensiktsmessig. Flere uttrykte at de hadde godt utbytte av et helhetlig opplegg som kombinerte individuelt tilrettelagte tiltak og felles opplegg i gruppe. De påpekte også at tiltakene hadde en god balanse mellom det fysiske og det psykiske.

\section{三 «Pasientene fikk større bevissthet om faktorer som påvirker hverdagen og lærte hvordan de skulle håndtere dem mer hensiktsmessig.»}


Da vi analyserte skjemaene, fant vi også pasienter som bare hadde en liten bedring av smerter og tretthet eller slapphet. Likevel oppga de at de hadde det bedre alt i alt. Det kan være flere årsaker til dette. Det som karakteriserte disse pasientene, var at de oppga at de hadde aktiviteter i hverdagen som ga dem mening og positive opplevelser til tross for de kroniske plagene. De kunne være opptatt av barnebarn og kjæledyr eller hobbyer som blant annet kunst, håndarbeid, snekkerarbeid, blomster og hage, musikk og turer i naturen.

\section{Tristhet/depresjon}

Denne variabelen hadde en svak tendens til bedring på 0,3 fra 2,6 til 2,3. Det var ganske mange som skåret lavt ved innskrivingen, altså at de hadde lav grad av tristhet og depresjon.

\section{$\equiv$ «Noen oppdaget at de aldri slappet av, andre at det fantes små gleder $\mathrm{i}$ hverdagen.»}

I noen få tilfeller så vi faktisk at pasientene skåret høyere på denne variabelen ved utreise, det vil si at de oppga større grad av tristhet og depresjon enn ved innkomst. Vi antar at det kunne være relatert til trygghet, tillit og åpenhet; underveis i prosessen ble pasientene mer kjent med oss og hverandre, og de ble ærligere.

Noen oppdaget at de aldri slappet av, andre at det fantes små gleder i hverdagen. Med ny innsikt erkjente og aksepterte de mer de faktiske forholdene i sin egen situasjon. Dermed innså de også at de hadde valg og mulighet til å gjøre en endring. I og med at vi likevel fikk en statistisk bedring, kan en uttalelse fra en pasient være med på å underbygge denne: «De har hjulpet meg ut av en mørk tunnel til en lys hverdag.»

\section{Smerter i ro og bevegelse}


Når det gjelder variablene «smerter i ro» og «smerter i bevegelse», ser vi en svak tendens til bedring. Smerter i ro gikk ned fra 3,7 til 3,4 $(-0,3)$, mens smerter i bevegelse gikk ned fra 5,1 til 4,7 $(-0,4)$.

Flere momenter kan ha spilt en rolle her. Pasientene kan ha kommet i gang med mer aktivitet enn de er vant til. Flere rapporterte om at kroppen reagerte med mer smerter underveis i rehabiliteringsperioden, men at det stabiliserte seg etter hvert.

Dersom en revmatisk pasient er inne i en aktiv sykdomsperiode i løpet av dagoppholdsperioden, kan det virke inn på hvor mye bedre pasienten blir. De som har en høy sykdomsaktivitet, kan få liten grad av bedring.

Andre faktorer som kan ha medvirket til den lille framgangen i resultatene våre, er at pasientene kommer på dagopphold til oss. De bor hjemme med hverdagens utfordringer, som ikke er like tydelige når de er på døgnopphold innenfor spesialisert rehabilitering. For noen pasienter var psykiske belastninger med på å forsterke eller vedlikeholde plagene for flere av målevariablene.

For enkelte pasienter med kroniske, langvarige plager kunne en periode på to dager i uken over fem uker kanskje være for kort til å få en merkbar bedring i smerter og andre fysiske funksjoner. Flere av pasientene uttrykte at rehabiliteringsperioden kunne vært lengre.

\section{Matlyst}

Denne variabelen gikk ned fra 7,4 til 6,6 - en nedgang på 0,8 . Ved innkomst hadde de god matlyst. Matlysten kan gi et bilde på hvordan pasienten har det og var en viktig del av helheten i skaleringsskjemaet.

Resultatene viser at de som fikk bedre søvn, også fikk bedre matlyst.

\section{Motivasjon til aktivitet}


Motivasjon til aktivitet gikk ned fra 7,3 til 6,7, altså en tilbakegang på 0,6. Da vi gikk inn og analyserte enkeltpasienter, så vi noen tilfeller av nedsatt motivasjon hos de pasientene som fikk mer smerter i løpet av oppholdet. Noen var inne i en aktiv sykdomsperiode, som kan ha ført til dalende motivasjon.

Pasientene som søkte seg inn på rehabilitering, virket motivert til aktivitet og hadde en gjennomsnittsverdi på 7,3, noe som må anses å være et godt utgangspunkt. En årsak kan være at de hadde en positiv forventning om tettere oppfølging over en periode.

Vi som fagpersoner er nær pasienten til enhver tid og tror at tett oppfølging av pasienten over en periode er med på å skape trygghet og motivasjon under aktivitetene hos oss. For flere er det vesentlig at de har noe forpliktende å forholde seg til, som faste avtaler med et konkret opplegg. Når den gjennomsnittlige motivasjonen dalte ved utreise, kan det skyldes at de ikke lenger fikk den samme tette oppfølgingen hos oss. Flere av våre pasienter uttalte dette.

Når det gjelder videre oppfølging av pasientene etter endt opphold, ser vi ofte at det kan være lengre ventetid for å bli videreført inn i et kommunalt behandlings- og treningsopplegg. Det kan også ha ført til nedsatt motivasjon.

\section{Kroppskart}

Resultatene av kroppskartene viste at 75 prosent av pasientene skraverte inn færre smerteområder ved utreise sammenliknet med innkomst. Vi så også en større tendens til at de skraverte smerteområdene på kroppskartet hadde svakere farge, noe som indikerte mindre smerter. 
I de tilfellene der hovedområdet for smerte var det dominerende ved oppstart, kunne dette smerteområdet være mer eller mindre borte ved utreise. I stedet så vi at mindre dominerende smerter på andre kroppsdeler var blitt mer framtredende og kunne være dominerende ved utreise.

\section{Evalueringsskjemaet}

På flere av evalueringsskjemaene kommer det fram at pasientene syntes kombinasjonen av behandling, tilrettelagt fysisk trening og samtaler individuelt og $\mathrm{i}$ gruppe var en god kombinasjon for dem. I tillegg var pasientene få i gruppen, som gjorde miljøet trygt og samholdet bedre. Pasientene skulle også krysse av hvor stort utbytte de hadde av behandlingen.

72 prosent av pasientene oppga at de hadde et meget godt utbytte, og 28 prosent av pasientene oppga middels utbytte. Ingen av pasientene oppga ganske lite eller intet utbytte. Våre erfaringer er at pasienter som lever med kroniske, sammensatte plager, har behov for og nytte av et tverrfaglig spesialisert dagrehabiliteringstilbud. 